The Geneva Papers on Risk and Insurance, 23 (No. 86, January 1998), 52-67

\title{
The Reinsurer's Strategic Objectives An Analysis Applying the Theoretical Framework of Prescriptive Decision Theory
}

\author{
by Matthias Graumann*
}

\section{Introduction}

This article has two intentions. The first intention is to develop strategic objectives for reinsurers. This article is prescriptive and not descriptive. It is not the objectives which reinsurers have that are analysed but rather the objectives reinsurers could have. The analysis is based on numerous assumptions. This leads to the second intention of the article. The second intention is to show how much the strategic objectives depend on the assumptions made. There is no such thing as "the strategic objectives" of reinsurers. There are only certain strategic objectives depending on certain assumptions. Only if a reinsurer accepts each and every assumption should it also accept the deduced strategic objectives.

\section{Basic assumptions}

The most basic assumption is that strategic objectives are analysed in the theoretical framework of Prescriptive Decision Theory1. In this view strategic objectives are part of strategic decisions. Strategic decisions are decisions which can be charactarised by two features: firstly, they strongly influence a company's performance over a long time and, secondly, they strongly influence other subsequent, more concrete, operational decisions (Mintzberg, 1978, p. 935).

The following analysis is based on the perspective of one reinsurance company called "the reinsurer". It is assumed that the reinsurer is a pure reinsurer, i.e. does not underwrite direct insurance business.

* Am Rinkenpfuhl 28, D-50676 Cologne, Germany.

${ }^{1}$ Another name for this theory is "Decision Analysis" (Keeney/Raiffa, 1976, p. 5). 
As already mentioned, strategic objectives are part of strategic decisions. For analysing strategic objectives reference is made to two theoretical concepts which form part of Prescriptive Decision Theory: the Decision Model Concept and the Decision Process Concept. The Decision Model Concept (see figure 1) serves to structure decisions into three components (Menges, 1969, p. 75): conditions, actions and objectives. The importance of objectives is evident: Conditions and actions are determined by the objectives insofar as the decision-makers only have to think about conditions and actions which influence the objectives. This is also valid for strategic decisions. Before thinking about strategic actions (the so-called "strategies") the strategic objectives must be fixed.

Figure 1: Decision Model Concept

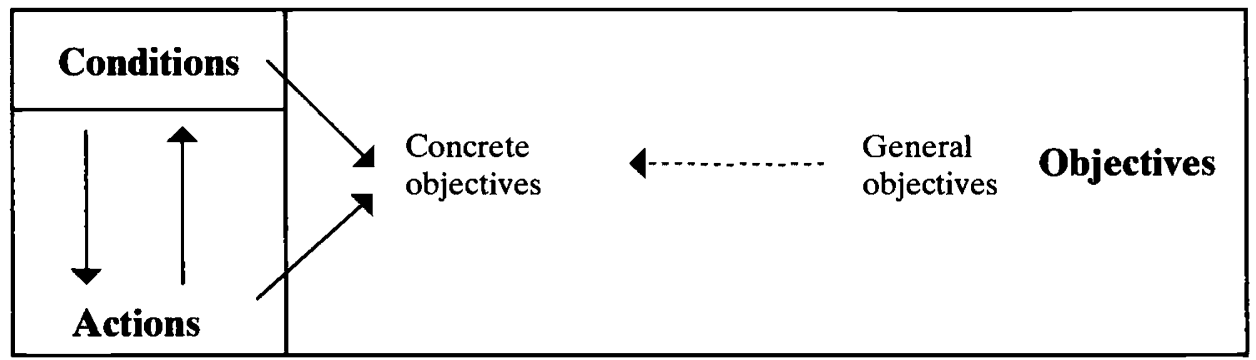

$\longrightarrow$ One variable influences another variable
$\ldots . \ldots . . . . \rightarrow \quad$ General variables are transformed into concrete variables

The Decision Model Concept shows that strategic objectives are one important component of strategic decisions. The Decision Process Concept shows that strategic objectives depend on three meta-decisions which the reinsurer has to make. From a prescriptive point of view a decision process has four phases (Weber, 1992, p. 1436). All three meta-decisions belong to the first phase, termed as "fixing phase" here. In this phase the decision problem is described and may be simplified. Then the method for modelling the decision-maker's preferences is chosen. Only then can the strategic objectives be fixed. The three meta-decisions are, in other words:

- Which strategic decision problem does the reinsurer want to solve?

- Is the original strategic decision problem so complex that it needs to be simplified?

- Which is the appropriate method for modelling the reinsurer's preferences?

After the "fixing phase" the reinsurer has to work through three more phases. The second phase is the "analysis phase". In this phase conditions and actions (the "strategies") are modelled and consequences on the strategic objectives are estimated. The third phase is the "evaluation phase". In this phase the consequences for the strategic objectives are evaluated. The evaluation depends on the preference modelling method chosen in the definition phase. The fourth phase is the "choice phase". The strategy which was best evaluated in the evaluation phase is chosen. 
The following analysis shows how the three meta-decisions influence the fixing of the reinsurer's strategic objectives.

\subsection{First meta-decision: describing the strategic decision problem}

Which strategic decision problem does the reinsurer want to solve? To answer this question it is assumed here that a reinsurance company has two major operations: the reinsurance operation and the capital investment operation. It is further assumed that the reinsurer only wants to solve the strategic decision problem which is related to the reinsurance operation. Within the reinsurance operation, two groups of strategic decision problems can be distinguished (Osterloh/ Frost, 1996, p. 144): "market-oriented strategic decision problems" and "resource-oriented strategic decision problems". Market-oriented strategic decision problems are based on the assumption that strategic success is mainly influenced by market-specific features, e.g. intensity of competition, barriers to entry, substitutional products, supply power and demand power (Porter, 1988, p. 4 ff.). Resourceoriented strategic decision problems are based on the assumption that strategic success is mainly influenced by company-specific resources, the so-called "core competences" (Prahalad/Hamel, 1990, p. 290 ff.). Regarding the reinsurer's strategic decision problem it is assumed here that the reinsurer's strategic success is more influenced by market-specific features than by its ability to develop company-unique core competences. It is, therefore, assumed here that the reinsurer wants to solve a market-oriented strategic decision problem.

\subsection{Second meta-decision: simplifying the strategic decision problem}

Whenever a decision problem is very complex, i.e. has many variables and many interactions between the variables, it should be simplified (Beer, 1972, p. 65). The simplification can take place by either dividing the original decision problem into subproblems or by leaving one decision problem while eliminating variables and/ or interactions within the decision problem (Frese, 1971, p. 294 ff.). Market-oriented strategic decision problems are usually regarded as being so complex that they need to be simplified by splitting them up into different sub-problems (Hofer/Schendel, 1978, p. 27 ff.).

In the case of the reinsurer, four strategic sub-problems exist, which are to be solved sequentially and recurrently (Graumann, 19973), pp. 600f:

a) Which potential markets should the reinsurer choose?

(A reinsurer's market is defined here as the combination of regions and customers located in the regions.)

b) Which potential businesses should the reinsurer choose?

(A reinsurer's business is defined here as the combination of markets and products. An equivalent description of this decision problem is: How should the reinsurer compete against his competitors in the chosen markets? in other words: The reinsurer looks for a "competitive strategy".)

c) Which effective businesses should the reinsurer choose?

(It may be that businesses that look attractive in isolation, i.e. in sub-problem b), may look less attractive when combined with other businesses. Therefore, sub-problem c) deals with the question of how to find the best combination of businesses.) 
d) What should the reinsurer do in the main functional areas of its company to support the effective businesses chosen in sub-problem c)?

(A reinsurer's main functional areas are underwriting, administration, claims management and finance.)

It is important to note that the reinsurer's strategic objectives vary from sub-problem to sub-problem. The strategic objectives which are developed in this article only refer to strategic sub-problem b)! They do not refer to strategic sub-problems a), c) and d).

\subsection{Third meta-decision: choosing the preference modelling method}

After the market-oriented strategic decision problem and the simplified sub-problem b) have been described the reinsurer must choose the appropriate method of modelling his preferences. The most important methods are the Expected Utility Method and the Safety First Method. Both methods can be used for supporting decisions which involve a high degree of uncertainty. A high degree of uncertainty is without any doubt given when the reinsurer tries to solve strategic decision sub-problem b). The Expected Utility Method is a famous and well-established method in administrative science (Schneeweiß, 1967, p. 61 ff.). The Safety First Method is a method which has recently been discussed for insurers and reinsurer (Schradin, 1991, p. 70 ff.). The reason for the importance of these methods is that the Expected Utility Method and the Safety First Method are based on axioms. If the reinsurer accepts the axioms of a method the method is an important tool for supporting its strategic decision. No empirical research is, however, available on whether or not reinsurers approve of the axioms of the Expected Utility Method or of the Safety First Method. On which method should the analysis be based here? This question is important to ask because both methods lead to different strategic objectives. To answer this question the analysis follows an assumption made by Albrecht (Albrecht, 1994, p. 14). Albrecht does not refer to the reinsurer's strategic decision sub-problem b) but to an insurer's corporate decision problem. The corporate decision problem is the fundamental and all-embracing problem of what to do in a company (Farny, 1985, p. 28). The strategic decision problem described under 2.1 is already a simplification of a company's corporate decision problem.

Albrecht shows that the Safety First Method and the Expected Utility Method lead to different corporate objectives. He further assumes that the different corporate objectives imply a difference in the use of information for solving the corporate decision problem. ${ }^{2}$ Then he assumes that the difference in the use of information implies a difference in the level of power of the solution to the corporate decision problem (see figure 2).

Figure 2: Albrecht's Reasoning

\begin{tabular}{|c|c|c|c|}
\hline $\begin{array}{l}\text { Different } \\
\text { preference } \\
\text { modelling } \\
\text { methods }\end{array}$ & $\begin{array}{l}\text { Different } \\
\text { corporate } \\
\text { objectives }\end{array}$ & $\begin{array}{l}\text { Different } \\
\text { use of } \\
\text { information }\end{array}$ & $\begin{array}{l}\text { Different levels of } \\
\text { power of the } \\
\text { solutions to the } \\
\text { corporate decision } \\
\text { problem }\end{array}$ \\
\hline
\end{tabular}

2 Only the Safety First Method enables the insurers to use the so-called "chance constrained programming" (Kirby, 1970, p.93 ff.). 
Albrecht is of the opinion that the use of the Safety First Method implies a higher level of power for the solution to the corporate decision problem than the use of the Expected Utility Method. As already mentioned, Albrecht refers to an insurer's corporate decision problem, not to the reinsurer's strategic sub-problem b). It is, however, assumed here that Albrecht's reasoning is also valid for the reinsurer's strategic sub-problem b). Therefore, it is assumed that the reinsurer uses the Safety First Method for modelling its preferences.

Figure 3 gives an overview of the assumptions made so far.

Figure 3: Assumptions

\section{Basic assumption: Perspective Decision Theory}

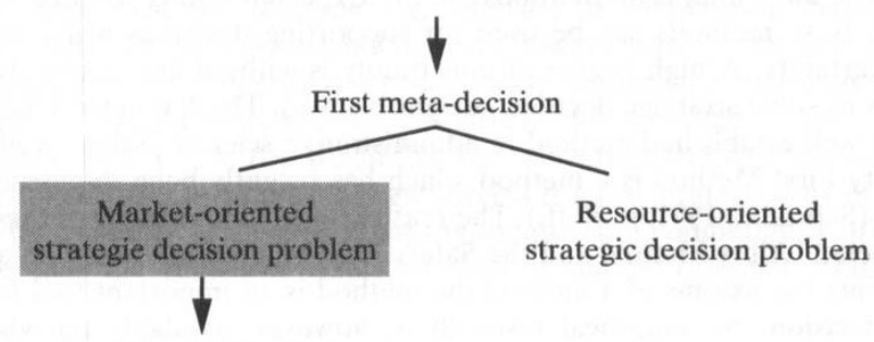

Second meta-decision

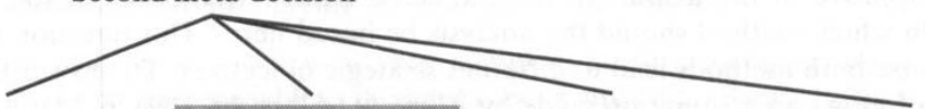

Sub-problem a): potential markets

Sub-problem b):

potential businesses

Sub-problem c): effective businesses
Sub-problem d): functional areas

Third meta-decision

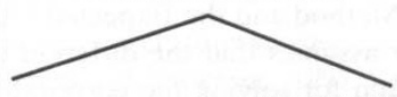

Expected Utility Method

Safety First Method

\section{Fixing the Reinsurer's Strategic Objectives}

Before the reinsurer's strategic objectives are further analysed a brief reference must be made to certain criteria which were elaborated in the Prescriptive Decision Theory. These criteria serve to support the fixing of objectives.

\subsection{Criteria for defining objectives}

The quality of a decison depends very much on the fixing of the objectives. If the fixing of the objectives fulfils all the subsequently described criteria the quality of the 
decision will be higher than it would have otherwise been. The criteria are (Eisenführ/ Weber, 1993, p. 58 ff.):

1) The objectives must be defined precisely.

2) No redundancies are allowed among the objectives, i.e. one objective must not be a part of another objective.

3) The number of objectives should be as small as possible to reduce the complexity of the decision problem.

4) The consequences of potential actions must be measurable against the objectives.

\subsection{Starting point: the reinsurer's corporate objectives}

Corporate objectives are divided into "monetary objectives" and "non-monetary objectives" (Farny, 1966, p. 135). The monetary corporate objectives depend on the preference modelling method. The Safety First Method which is the basis for the analysis here leads to the following monetary corporate objectives (Albrecht, 1994, p. 13 f.):

- Maximise the mean of the profit probability distribution!

- Keep the pure reinsurance ruin probability under a tolerance level $\epsilon$ !

Profit is defined as the difference between turnover (i.e. the total of reinsurance premiums) and costs. Costs are net loss costs, retrocession costs, equity costs and administration costs (Farny, 1994, p. 168). Pure reinsurance ruin probability is defined as the probability that net loss costs are bigger than the reinsurer's equity plus the net-lossrelated parts of the reinsurance premiums (von der Schulenburg, 1981, p. 34 ff.). The netloss-related parts of the reinsurance premiums are the amount of money which is designed to pay net losses (Schwake, 1987, p. 178). This amount of money is termed "net-losspaying premiums" here. The tolerance level $\epsilon$ is a figure between $0 \%$ and $100 \%$. In reinsurance practice $\epsilon$ usually has a value which is either $1 \%$ or $5 \%$. It must be stressed that the ruin probability only refers to the reinsurance operation and not to the capital investment operation of the reinsurance company. The ruin probability is, therefore, termed "pure reinsurance ruin probability".

No research has so far been done into the reinsurer's non-monetary corporate objectives. It is assumed here that the reinsurer's non-monetary corporate objectives are similar to the insurer's non-monetary corporate objectives. These are (Farny, 1995, p. 290 f.): creating a good image, being independent, exercising power and keeping companyspecific traditions. In addition to this, the following objectives could be added: creating safe jobs for the employees, establishing good human relations among the employees and protecting the environment.

\subsection{The reinsurer's monetary strategic objectives: pure reinsurance ruin probability and profit}

It is realistic to assume that reinsurers have monetary and non-monetary strategic objectives. Here, the analysis is restricted to the monetary strategic objectives. It is assumed that the reinsurer's monetary strategic objectives of strategic sub-problem $b$ ) are identical with the reinsurer's monetary corporate objectives. The reinsurer's monetary strategic objectives are, therefore, "keep the pure reinsurance ruin probability below a 
tolerance level $\epsilon$ !" and "maximise the mean of the profit probability distribution!". These two objectives fulfil criteria 1),2) and 3) outlined in 3.1, but they do not fulfil criteria 4). The two objectives are too general to measure the consequences of potential strategies. Therefore, more concrete monetary strategic objectives must deduced from the two general monetary strategic objectives.

\subsubsection{Deductions from pure reinsurance ruin probability}

The pure reinsurance ruin probability depends on three variables (Albrecht, 1982, p. 523): the net-loss-paying premiums, the net losses and the reinsurer's equity. It is assumed here that the reinsurer's equity is given when the reinsurer solves strategic sub-problem $b$ ). Then the pure reinsurance ruin probability can be transformed into the following more concrete strategic objectives:

- Maximise the net-loss-paying premiums!

- Minimise the net losses!

The strategic objective "Minimise the net losses!" is not yet concrete enough to measure the consequences of potential strategies. The probability distribution of the total net losses depends on the features of the reinsurance portfolio. The reinsurance portfolio is the aggregate of everything which is underwritten by the reinsurer. In reinsurance practice the term "everything" is usually replaced by the term "risks". According to this terminology the reinsurance portfolio is the aggregate of all risks underwritten by the reinsurer. The different risks are numbered here with the index $x_{d}$. The risks $s_{d}$ are clustered into segments (Gerathewohl, 1980, p. 150) which are numbered here with the index $x_{D}$. Potential clusters are regions, customers, proportional vs. non-proportional reinsurance products, obligatory vs. facultative reinsurance products, long-term vs. short-term reinsurance products, property vs. casualty reinsurance products, and so on.

The concrete strategic objectives related to the features of the reinsurance portfolio are (Albrecht, 1984, p. 194 ff.):

- Maximise the homogeneity of the loss probability distributions of the risks $s_{d}$ in cluster ${ }_{D}$ !

- Maximise the independence of the loss probability distributions of the risks $s_{d}$ in cluster $_{D}$ !

- Maximise the quantity of risksd in cluster $_{D}$ !

- Minimise the deviations of the loss probability distributions of the clusters ${ }_{\mathrm{D}}$ !

\subsubsection{Deductions from profit}

Profit depends on turnover and costs. It seems reasonable to assume that strategic objectives can be deduced from turnover as well as from costs. The following analysis will show whether this assumption is correct.

\subsubsection{Turnover-related deductions: form turnover to bargaining power and cedant's satisfaction}

The general strategic objective is "Maximise the Turnover!". This objective fulfils criteria 1),2) and 3) outlined under 3.1 but it does not fulfil criteria 4). The objective is too 
general to measure the consequences of potential strategies. It has to be made more concrete.

It is assumed that the most important variables influencing a company's turnover are the institutions on the markets (Porter, 1988, p. $27 \mathrm{ff}$.). From the reinsurer's point of view these institutions are cedants, brokers, competitors and suppliers. According to criterion 3 ) outlined in 3.1 , the complexity of strategic decision sub-problem b) can be reduced by referring only to the institution which influences the reinsurer's turnover the most. This institution is the cedant. Thus, the more concrete strategic objective is: "influence the cedant so that turnover is maximised!"

Any attempt on the part of the reinsurer to influence the cedant must focus on the negotiations between the cedant and the reinsurer. This is a reasonable approach because in reinsurance no business transaction is done without negotiations (Angeli, 1981, p. 3). Negotiations are characterised by the fact that the reinsurer and the cedant communicate with each other to exchange goods (Schelling, 1960, p. $21 \mathrm{ff}$.). On the following page figure 4 shows a negotiation model based on the Decision Model Concept outlined under 2. The negotiation model assumes that threats have an important influence on the outcome of negotiations (Hicks, 1964, p. 140 and Schelling, 1956, p. 292 ff.). This is also the case when the reinsurer and the cedant negotiate with each other. The Reinsurer can threaten not to sell; the cedant can threaten not to buy. Both reinsurer and cedant have the objective of maximising the credibility of their threats (Stevens, 1963, p. 77).

It is stressed that the variables shown in figure 4 refer to operational decisions in negotiations. It has not yet been analysed which of these variables can be influenced by the reinsurer's strategic decision concerning strategic sub-problem $b$ ). With respect to this question, the following assumptions are made: the reinsurer's actions in the negotiation model are pure operational actions. Thus, they cannot be influenced by a strategic decision. The same applies to the conditions "cedant's commitment" and "cedant's communication to the reinsurer". The only variable which can be influenced by a strategic decision concerning strategic sub-problem b) is the condition "cedant's procurement". The cedant's procurement can be influenced by influencing the variables termed "other conditions" (see figure 4). The extent to which a reinsurer can influence these "other conditions" can be interpreted as the reinsurer's bargaining power (Levinson, 1966, p. 6 ff.). The reinsurer's bargaining power will increase if

- the cedant's satisfaction with the reinsurer increases.

- the cedant's satisfaction with other reinsurers decreases.

- the cedant's costs of change increase.

- the cedant's need for reinsurance increases.

- the probability of obtaining reinsurance products from other reinsurers decreases.

- the cedant's financial resources decrease.

- the cedant's chance of backwards integration decreases.

- the standardisation level of the reinsurance products decreases.

At this point of the analysis the strategic objective "Influence the cedant so that the turnover is maximised!" can be transformed into the more concrete strategic objective 
Figure 4: Negotiation Model

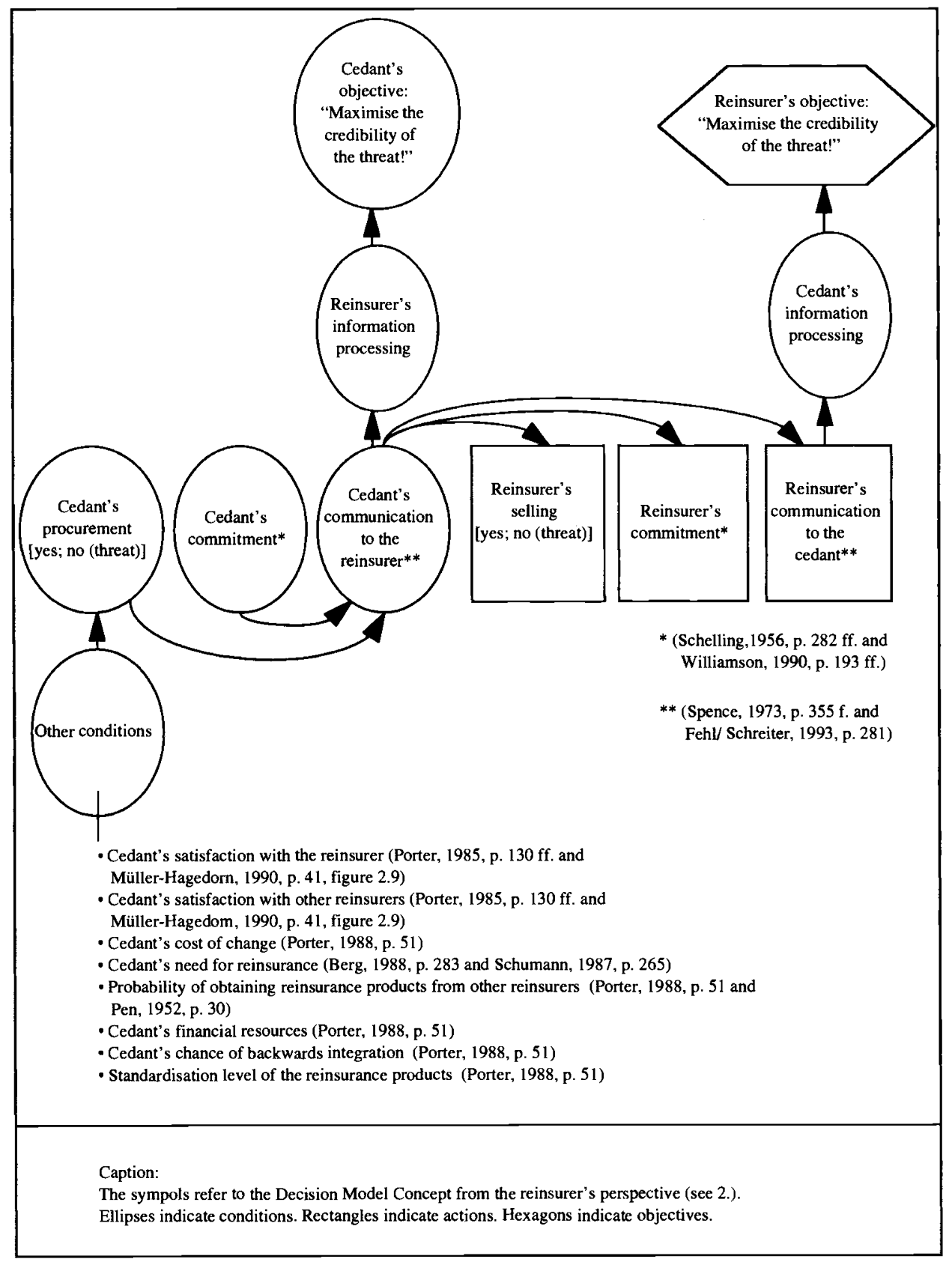


"maximise the reinsurer's bargaining power!". From an operational point of view the reinsurer's bargaining power can be influenced by influencing all the variables termed "other conditions" in the above-mentioned way. From a strategic point of view the reinsurer's bargaining power can be influenced by influencing only three of the "other conditions": the cedant's satisfaction with the reinsurer, the cedant's costs of change and the standardisation level of the reinsurance products. The strategic objective "maximise the reinsurer's bargaining power!" can, therefore, be made more concrete by regarding these three influencing variables as strategic objectives. The importance of these three variables is, however, different. The cedant's costs of change are very small and do not significantly influence the reinsurer's bargaining power. According to criterion 3 ) outlined in 3.1, the cedant's costs of change should be neglected to keep the number of strategic objectives as small as possible. Potential concrete strategic objectives are "minimise the standardisation level of the reinsurance products!" and "maximise the cedant's satisfaction!". A definition like this would, however, not fulfil criterion 2) outlined under 3.1 because of the redundancy between the two objectives. The cedant's satisfaction is higher the lower the standardisation level of the reinsurance products is (Jannott, 1988, p. 716). A potential objective "minimise the standardisation level of the reinsurance products!" is, therefore, already included in the objective "maximise the cedant's satisfaction!". Thus, the strategic objective "maximise the bargaining power!" is transformed into the more concrete strategic objective "maximise the cedant's satisfaction!".

According to criterion 1) outlined in 3.1 , a precise definition of the term "cedant's satisfaction" is necessary. In general, it is assumed that a customer will be satisfied if his objectives are sufficiently realised (Kottler, 1982, p. 15 f.). According to this, the cedant will be satisfied if his objectives for buying reinsurance products are sufficiently realised. The strategic objective "maximise the cedant's satisfaction!" can therefore be transformed into the more concrete objectives the cedant has for buying reinsurance products. Some empirical research has been done into the objectives cedants have in the German reinsurance market (Helten, 1985, p. 53 ff. and Schenk, 1995, p. 363 ff.). The empirical research does not, however, fulfil criteria 1) (precise definitions) and 2) (no redundancies) outlined in 3.1. To fulfil these criteria, reference is made to a theoretical approach (Graumann, 19971, p. 368).

According to this approach the potential objectives of a typical cedant are:

1) Keep the pure insurance ruin probability under a tolerance level $r$ !

2) Maximise the underwriting capacity!

3) Reduce the necessary solvency-related capital!

4) Maximise the autonomy regarding the annual report policy!

5) Enhance the liquidity!

6) Minimise the costs caused by reinsurance administration!

7) Realise a partnership with the reinsurer!

8) Improve activities in the value chain!

These objectives are related to a "typical cedant". It is, however, necessary to distinguish between different categories of cedants (Mahlstedt, 1988, p. 1317). Cedants can 
be distinguished by two features (Graumann, $1997^{2}$, p. $290 \mathrm{f}$.): the cedant's objectives in buying reinsurance products and the cedant's price elasticity of demand. This leads to the two categories of cedants shown in figure $5^{3}$

Figure 5: Categories of Cedants

\begin{tabular}{|l|l|l|}
\hline Categories of cedants & $\mathrm{X}$ & $\mathrm{Y}$ \\
\hline $\begin{array}{l}\text { Objectives for buying } \\
\text { reinsurance products }\end{array}$ & $1)-8)$ & $1)-7)$ \\
\hline Price elasticity of demand & Low & High \\
\hline
\end{tabular}

The decision as to which category to choose belongs to strategic sub-problem a) described in 2.2. The reinsurer's three potential actions are to do business with either category $\mathrm{X}$ or category $\mathrm{Y}$ or to do business with both categories $\mathrm{X}$ and $\mathrm{Y}$. The turnoverrelated concrete strategic objectives of sub-problem $b$ ) obviously depend on the decision concerning sub-problem a).

If the reinsurer decides to do business with category $\mathrm{X}$, the strategic objective "maximise the cedant's satisfaction!" can be transformed into the following concrete strategic objectives:

1) Keep the cedant's pure insurance ruin probability under a tolerance level $\rho$ ! The cedant's pure insurance ruin probability depends on three variables (Albrecht, 1982, p. 523): the cedant's net-loss-paying premiums, the cedant's net losses and the cedant's equity. The reinsurer cannot influence the cedant's equity. Thus, the more concrete strategic objectives are "maximise the cedant's net-loss-paying premiums!" and "minimise the cedant's net losses!". The strategic objective "minimise the cedant's net losses!" is not yet concrete enough to measure the consequences of potential strategies (see 3.3.1). It can be transformed into the concrete strategic objectives "maximise the homogeneity of the cedant's loss probability distributions of the risks ${ }_{\mathrm{k}}$ in cluster $_{\mathrm{K}}$ !" and "minimise the cedant's deviations of the loss probability distributions of the clusters ${ }_{K}$ !" (Albrecht, 1984, p. 194 ff.). It should be noted that the reinsurer can influence neither the independence of the cedant's loss probability distributions of the risks ${ }_{k}$ in cluster $_{K}$ nor the cedant's quantity of risks $\mathrm{k}_{\mathrm{k}}$ in cluster $_{\mathrm{K}}$.

2) Maximise the cedant's underwriting capacity!

3) Reduce the cedant's necessary solvency-related capital!

\footnotetext{
${ }^{3}$ It is hereby assumed that the two features depend on each other, i.e. a certain price elasticity of demand corresponds with certain objectives in buying reinsurance products.
} 
4) Maximise the cedant's autonomy regarding its annual report policy!

5) Enhance the cedant's liquidity!

6) Minimise the cedant's costs caused by reinsurance administration!

7) Realise a partnership with the cedant! This objective can be made more concrete by defining the objectives "maximise the cedant's trust in the reinsurer!" and "maximise the cedant's fun with the reinsurer!" (Bayerische Rückversicherung Aktiengesellschaft, 1988, p. 3 and Blanc, 1965, p. 214)

8) Improve the cedant's value chain!

If a reinsurer decides to do business with category $\mathrm{Y}$ the strategic objective "maximise the cedant's satisfaction!" is transformed into the above-mentioned concrete strategic objectives 1) - 7); objective 8) is not relevant. If a reinsurer decides to do business with category $\mathrm{X}$ as well as with category $\mathrm{Y}$, the strategic objectives differ from category to category.

\subsubsection{Cost-related deductions?}

Profit depends on the two components "turnover" and "costs". After concrete strategic objectives have been successfully deduced from the turnover component, the question arises as to whether it is also possible to deduce strategic objectives from the cost component. The straight-forward answer is "no" and this answer is due to criterion 2) outlined in 3.1. An attempt to deduce strategic objectives from the cost component would result in redundant strategic objectives. There are two reasons for this.

The first reason is that minimising the reinsurer's costs is already required by the strategic objective "maximise the cedant's net-loss-paying premiums!". The cedant's netloss-paying premiums are influenced by the prices of the reinsurance products which depend on the reinsurer's costs. From an operational point of view, the prices depend on many more influential variables than just the costs (Meffert, 1986, p. 262 ff.). But from the strategic point of view it is reasonable to regard the costs as the variable which influences the prices of the reinsurance products the most. As a consequence of this, the reinsurer is already obliged to minimise its costs in order to influence the strategic objective "Maximise the cedant's net-loss-paying premiums!" in a positive way. The fixing of a further strategic objective like "minimise the reinsurer's costs!" would only imply a redundancy. That redundancy must be avoided.

The second reason is that minimising the reinsurer's net loss costs is already a strategic objective which has been transformed into more concrete objectives (see 3.3.1). The fixing of a further strategic objective like "Minimise the reinsurer's net loss costs!" would only imply a redundancy. That redundancy must be avoided. To sum up, no strategic objectives can be deduced from the cost component.

\section{Summary}

The first intention of this article was to develop strategic objectives from the perspective of a typical reinsurance company termed "the reinsurer". The second intention of this article was to show how much the strategic objectives depend on certain assumptions. The basic assumption was to develop strategic objectives in the theoretical 
framework of Prescriptive Decision Theory. According to this theory the reinsurer's strategic objectives depended on three meta-decisions. The first meta-decision was to describe the strategic decision problem the reinsurer wanted to solve. Here, the decision problem was described as a market-oriented decision problem not as a resource-oriented decision problem. The second meta-decison was to simplify the market-oriented decision problem by splitting it up into four sub-problems. From the four sub-problems only the sub-problem of choosing potential businesses, i.e. combinations of markets and products, was further analysed. The third meta-decision was to choose the method with which the reinsurer's preferences were modelled. Here the Safety First Method was prefered to the Expected Utility Method. After the meta-decisions had been made four criteria developed in Prescriptive Decision Theory were presented. It was assumed that the reinsurer's strategic objectives had to fulfil all four criteria to increase the quality of the strategic decision. Then the reinsurer's corporate objectives were analysed. It was assumed that the monetary corporate objectives "keep the pure reinsurance ruin probability under a tolerance level e!" and "maximise the mean of the profit probability distribution!" were identical with the reinsurer's monetary strategic objectives. From these general strategic objectives a number of concrete strategic objectives was deduced.

The reinsurer's monetary strategic objectives are shown in an overview on the following page (see figure 6). The concrete strategic objectives are shaded to distinguish them from the general strategic objectives. The arrows indicate that general strategic objectives are influenced by concrete strategic objectives in a positive way. Expressions in brackets indicate influencing variables which are not strategic objectives.

Figure 6: "Monetary Strategic Objectives"

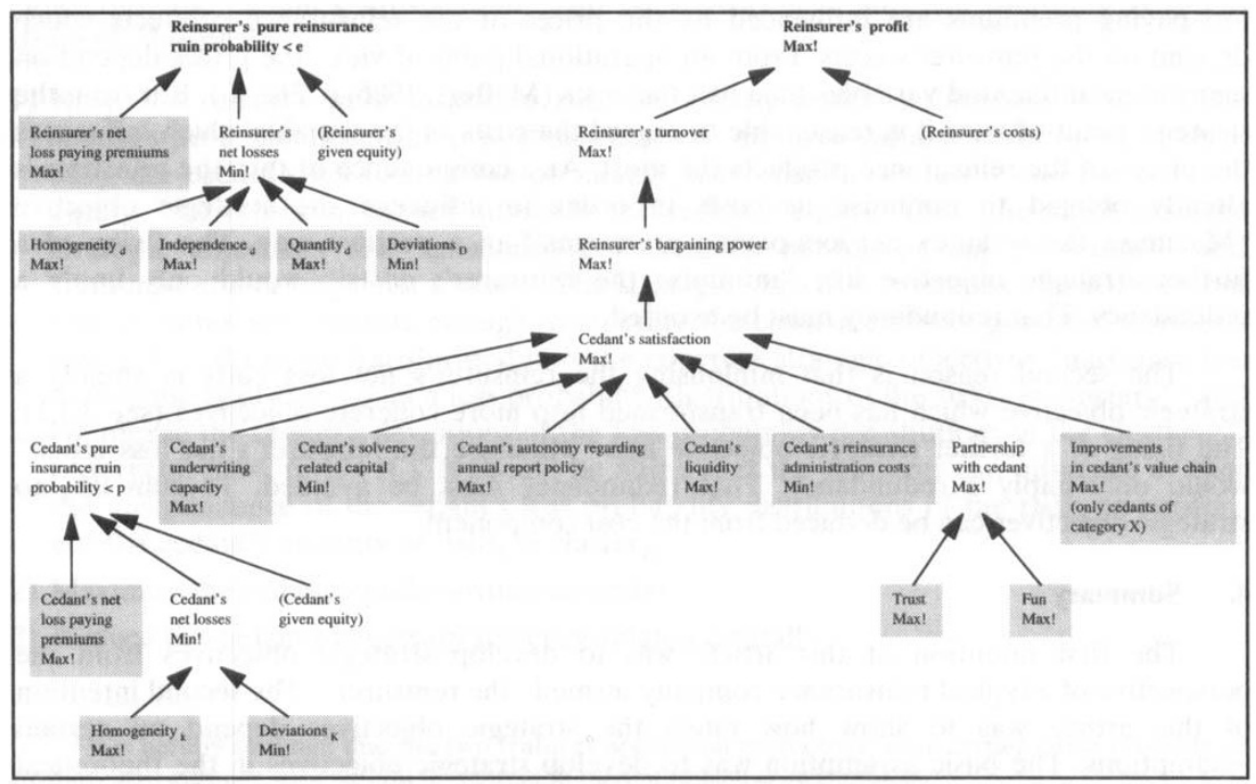




\section{BIBLIOGRAPHY}

ALBRECHT, P. (1982); “Gesetze der großen Zahlen und Ausgleich im Kollektiv - Bemerkungen zu Grundlagen der Versicherungsproduktion"; Zeitschrift für die gesamte Versicherungswissenschaft, Vol. 71, pp. 501-538.

ALBRECHT, P. (1984); “Welche Faktoren begünstigen den Ausgleich im Kollektiv?”; Zeitschrift für die gesamte Versicherungswissenschaft, Vol. 73, pp. 181-201.

ALBRECHT, P. (1994); "Gewinn und Sicherheit als Ziele der Versicherungsunternehmung: Bernoulli-Prinzip vs. Safety first-Prinzip"; Dieter Farny und die "Versicherungswissenschaft", edited by R. Schwebler et al, Karlsruhe, pp. 1-18.

ANGELI, G. (1981); La Riassicurazione. Teoria, Pratica E Tematiche Varie, 2nd edition,Varese.

Bayerische Rückversicherung Aktiengesellschaft (1988); “Geschäft und Freundschaft”, Journal Nr. 6, Munich.

BEER, S. (1972); Brain of the Firm - The Managerial Cybernetics of Organization, London.

BERG, H. (1988); Wettbewerbspolitik; Vahlens Kompendium der Wirtschaftstheorie und Wirtschaftspolitik, Book 2, 3rd edition, Munich, pp. 231-291.

BLANC, H. le (1965); “The Human Factor in Reinsurance”; The Review, 26.02.1965, pp. 214-218.

EISENFÜHR, F.; WEBER, M. (1993); “Rationales Entscheiden”, Berlin and others.

FARNY, D. (1966); "Unternehmerische Ziel- und Mittelentscheidungen in der Versicherungswirtschaft”, Zeitschrift für die gesamte Versicherungswissenschaft, Vol. 55, pp. 129159.

FARNY, D. (1985); “Unternehmenspolitische Grundsatzentscheidungen europäischer Versicherer bis zum Ende unseres Jahrhunderts", Versicherungswirtschaft, Vol. 40, pp. 28-40.

FARNY, D. (1994); Einige Grundfragen der Prämienkalkulation in der Schadenversicherung; Die Vergangenheit bewahren - die Zukunft gewinnen, Festschrift der Alten Leipziger Versicherung Aktiengesellschaft zum 175jährigen Jubiläum, Oberursel, pp. 165-177.

FARNY, D. (1995);Versicherungsbetriebslehre, 2nd edition, Karlsruhe.

FEHL, U.; SCHREITER, C. (1993); Neuere Entwicklungen in der Preistheorie; Wirtschaftswissenschaftliches Studium, Vol. 22, pp. 276-285.

FRESE, E. (1971); Heuristische Entscheidungsstrategien der Unternehmungsführung; Zeitschrift für betriebswirtschaftliche Forschung, Vol. 23, pp. 283-307.

GERATHEWOHL, K. (1980); “Risk Management bei Erst- und Rückversicherer”; Zeitschrift für die gesamte Versicherungswissenschaft, Vol. 69, pp. 137-153.

GRAUMANN, M. (19971); “Ziele der Rückversicherungsnahme”; Versicherungswirtschaft, Vol. 52, 1997, pp. 367-370.

GRAUMANN, M. (19972); “Wettbewerbsstrategien der Rückversicherungsunternehmung"; Zeitschrift für Versicherungswesen, Vol. 48, 1997, pp. 290-299 and pp. 331-335.

GRAUMANN, M. (19973); Zur Wettbewerbsstrategie der Rückversicherungsunternehmung: Das strategische Teilentscheidungsproblem der Wettbewerbs-Grundstrategie, will be published in: Zeitschrift für die gesamte Versicherungswissenschaft, Vol. 86, pp 597-626.

HELTEN, E. (1985); Vom Nutzen der Rückversicherung aus Sicht der Erstversicherer; Rückversicherung - Anspruch und Selbstverständnis, Festschrift zum Einzug in das Verwaltungsgebäude der Eisen und Stahl und der Hannover Rück, edited by Eisen und Stah Rückversicherungs-AG und Hannover Rückversicherungs-AG, Karlsruhe, pp. 53-68. 
HICKS, J.R. (1964); The Theory of Wages, 2nd edition, London and others.

HOFER, C.W.; SCHENDEL, D. (1978); Strategy Formulation: Analytical Concepts, St. Paul.

JANNOTT, H.K. (1988); "Rückversicherungspolitik"; Handwörterbuch der Versicherung, edited by Dieter Farny et al, Karlsruhe, pp. 715-719.

KEENEY, R.L.; RAIFFA, H. (with a Contribution by R.F. Meyer) (1976); "Decisions with Multiple Objectives: Preferences and Value Tradeoffs", New York and others.

KIRBY, M.J.L. (1970); “The Current State of Chance Constrained Programming"; Proceedings of the Princeton Symposium on Mathematical Programming, edited by H.W. Kuhn, Princeton, pp. 93-11.

KOTTLER, P. (1982); "Marketing-Management"; Analyse, Planung und Kontrolle, 4th edition, Stuttgart.

LEVINSON, H.M. (1966); "Determining Forces in Collective Bargaining Negotiation”, New York and others.

MAHLSTEDT, I. (1988); "Segmentierung nach Kundengruppen beim Rückversicherer"; Geld, Banken und Versicherungen, 1987, Book 2, edited by W.-R. Heilmann, Karlsruhe, pp. 1315-1326.

MEFFERT, H. (1986); “Marketing, Grundlagen der Absatzpolitik", 7th edition, Wiesbaden.

MENGES, G. (1969); "Grundmodelle wirtschaftlicher Entscheidungen"; Einführung in moderne Entscheidungstheorien unter besonderer Berücksichtigung volks- und betriebswirtschaftlicher Anwendungen, Cologne and others.

MINTZBERG, H. (1978); "Patterns in Strategy Formulation”; Management Science, Vol. 24, pp. 934948.

MÜLLER-HAGEDORN, L. (1990); “Einführung in das Marketing”, Darmstadt.

OSTERLOH, M./ FROST, J. (1996); “Prozeßmanagement als Kernkompetenz”, Wiesbaden.

PEN, J. (1952); “A General Theory of Bargaining”; The American Economic Review, Vol. XLII, 1952, pp. 24-42.

PORTER, M.E. (1985); "Competitive Advantage. Creating and Sustaining Superior Performance", New York and others.

PORTER, M.E. (1988); “Wettbewerbsstrategie (Competitive Strategy)”; Methoden zur Analyse von Branchen und Konkurrenten, 5th edition, Frankfurt am Main.

PRAHALAD, C.K./ HAMEL, G. (1990); "The Core Competence of the Corporation", Harvard Business Review, Vol. 68, No. 3, pp. 79-91.

SCHELLING, T.C. (1956); “An Essay on Bargaining”; The American Economic Review, Vol. XLVI, pp. 281-306.

SCHELLING, T.C. (1960); "The Strategy of Conflict”, Cambridge MA.

SCHENK, P. (1995); "Rückversicherungsentscheidungen von Schaden- und Unfallversicherungsunternehmen"; Versicherungswirtschaft, Vol. 50, pp. 363-369.

SCHNEEWEIB, H. (1967); "Entscheidungskriterien bei Risiko”, Berlin and others.

SCHRADIN, H.R. (1994); "Erfolgsorientiertes Versicherungsmanagement. Betriebswirtschaftliche Steuerungskonzepte auf risikotheoretischer Grundlage", Karlsruhe.

SCHULENBURG, J.-M. Graf v. der (1981); "Theorie der Rückversicherung - Die Rückversicherungsformen im Lichte der ökonomischen Theorie der Entscheidungen unter Unsicherheit", Düsseldorf. 
SCHUMANN, J. (1987); “Grundzüge der mikroökonomischen Theorie”, 5th edition, Berlin and others.

SCHWAKE, E. (1987); “Überlegungen zu einem risikoadäquaten Marketing als Steuerungskonzeption von Versicherungsunternehmen", Karlsruhe.

SPENCE, M. (1973); “Job Market Signaling”; The Quarterly Journal of Economics, Vol. 87, pp. 355374.

STEVENS, C.M. (1963);“Strategy and Collective Bargaining Negotiation”, New York and others Weber, M. (1992); "Nutzwertanalyse"; Handwörterbuch der Organisation, edited by E. Frese, 3rd edition, Stuttgart, pp. 1435-1448.

WILLIAMSON, O.E. (1990); "Die ökonomischen Institutionen des Kapitalismus. Unternehmen, Märkte, Kooperationen”, Tübingen. 